\title{
Influence of flood frequency, temperature and population density on migration of Fundulus heteroclitus in semi-isolated marsh pond habitats
}

\author{
Karen L. Hunter ${ }^{1}$, Michael G. Fox ${ }^{2, *}$, Kenneth W. Able ${ }^{3}$ \\ ${ }^{1}$ Department of Geography, University of Victoria, PO BOX 3060 STN CSC, Victoria, British Columbia V8W 3R4, Canada \\ ${ }^{2}$ Environmental and Resource Studies Program and Department of Biology, Trent University, 1600 West Bank Drive, \\ Peterborough, Ontario K9J 7B8, Canada \\ ${ }^{3}$ Marine Field Station, Institute of Marine and Coastal Sciences, Rutgers University, 800 Great Bay Boulevard, Tuckerton, \\ New Jersey 08087, USA
}

\begin{abstract}
Fish respond to habitat and demographic factors that affect growth and survival through migration, reproduction and mortality. However, the importance of migration rates on fish population dynamics and the effects of habitat and demographic factors on movement are not well understood. We used mark-recapture to determine population dynamics (recruitment, mortality, immigration and emigration) of the mummichog Fundulus heteroclitus inhabiting semi-isolated ponds in a New Jersey salt marsh over the spring and summer of 2002. We tested the effects of marsh pond flood frequency, water temperature and fish density on mummichog emigration from marsh ponds. Results show that during the April to July study period, monthly emigration rates averaged $30 \%$ and tended to decline from spring to summer in most ponds. Recruitment and immigration were negligible after May and June, respectively. Increasing mortality and decreasing emigration and immigration over the study period suggested that there was a shift in the importance of movement in regulating mummichog population size in marsh ponds. The mean rate of emigration showed a significant negative relationship with the frequency of flooding in a pond. Neither mummichog density nor water temperature was strongly correlated with emigration rate. Our finding of lower emigration from ponds with higher flooding frequency suggests that frequent pond flooding indirectly triggers stationary behaviour in mummichogs because of enhanced water quality and food abundance.
\end{abstract}

KEY WORDS: Emigration · Flooding ' Marsh ponds · Fundulus heteroclitus · Mummichog · Population dynamics

Resale or republication not permitted without written consent of the publisher

\section{INTRODUCTION}

Movement is a condition-dependent trait attributed to the resolve of mobile animals to maximize fitness (Hanski \& Gilpin 1991, Kristan 2003). Individual movement responses to habitat and demographic factors such as predation risk (Werner et al. 1983), resource competition (Fretwell \& Lucas 1969) and abiotic conditions (McMahon \& Tash 1988) are often triggered by unsuitable conditions. Populations are dynamic because they increase and decrease as a result of individual responses to demographic and habitat factors. Characteristics that determine population-level change include recruitment, mortality, emigration and immigration. Despite their contribution to population processes, immigration and emigration data are frequently unavailable or their impacts perceived to be minimal; thus their importance in population dynamics is often unknown (McMahon \& Matter 2006).

Fish are highly mobile animals that use a variety of habitats which make them suitable study organisms for movement studies (Lucas \& Baras 2001). Specifically, salt marsh fish are adapted to using marsh habitats that serve a variety of ecological functions (Kneib 1997, Valiela et al. 2004), with multi-habitat uses by fish well documented in marshes (Fritz et al. 1975, Lotrich 1975, 
Halpin 1997, Able et al. 2006). The characteristic use of subtidal, intertidal and marsh surface habitats by a dominant and abundant resident marsh fish, the mummichog Fundulus heteroclitus (Fundulidae), is particularly important because the movements of this species between habitats provide a key trophic linkage between terrestrial and aquatic environments in coastal zones (Kneib \& Stiven 1978, Kneib 1986, Tupper \& Able 2000). While the use of marsh habitats by mummichogs is important from the perspective of marsh ecological processes (Kneib 1986), little is known about the population dynamics of this species in natural marshes.

Common features of salt marshes worldwide are marsh ponds scattered across their surface that provide habitat for fish and other marine benthic organisms. A unique element of marsh ponds is their exposure to tidal flooding that temporarily links their inhabitants to the marsh landscape. During a flood, mummichogs actively use the marsh surface for foraging (Weisberg \& Lotrich 1982, Kneib \& Wagner 1994) and they can move among marsh habitats (Whoriskey \& Fitzgerald 1989, Smith \& Able 1994). Flood timing in the marsh is relatively predictable, but flood magnitude can vary greatly, with periodic drought conditions, and can limit access to marsh surface habitat and thus affect fish migration patterns (Childers et al. 1990, Halupa \& Howes 1995). Marsh fish may be subjected to high fish density (Raposa \& Roman 2001), severe temperatures $\left(>40^{\circ} \mathrm{C}\right)$ and extremely low concentrations of dissolved oxygen (Smith \& Able 2003) between periods of flooding, particularly if low tidal periods persist (Childers et al. 1990).

It is not known whether habitat or demographic factors contribute to fish migration patterns on the marsh surface, or what role flooding plays in influencing movement. High temperatures or high population density in infrequently flooded ponds may contribute to population change through increased emigration rates during times of flooding (McMahon \& Tash 1988). In contrast, ponds that are subjected to more regular tidal flooding may be cooler and higher in oxygen concentration, as well as have increased productivity which provides more food resources for fish (Froneman 2002, Balcombe et al. 2005, 2007). Diminished exploration behaviour by individuals experiencing more suitable habitat conditions linked to tidal flooding may result in lower emigration rates (McMahon \& Matter 2006).

In the present study, we used mark-recapture to estimate monthly population size and migration, recruitment and mortality rates of mummichogs in ponds in the Sheepshead Meadows salt marsh (New Jersey, USA) during the spring and summer when reproduction and most of the somatic growth occurs in this species. The principal objectives of the present study were to determine monthly patterns in migration, recruitment and mortality rates of mummichogs inhabiting these ponds, and to specifically examine the effects of tidal flood frequency, population density and water temperature on the emigration rate of mummichogs. We predicted that mummichogs would emigrate at a higher rate from ponds with (1) more tidal flooding, (2) higher temperature, and (3) higher population density.

\section{MATERIALS AND METHODS}

Study area, ponds and on-site physical monitoring. The present study was conducted in the Sheepshead Meadows salt marsh, located near Tuckerton, New Jersey $\left(39^{\circ} \mathrm{N}, 74^{\circ} \mathrm{W}\right)$, on the northeast coast of the United States (Fig. 1). This site is one of the last unaltered marsh systems along the northeast coast (Lathrop et al. 2000). The study area has a large number of ponds on the marsh surface, ranging in size from 1 to $>1000 \mathrm{~m}^{2}$, with a mean pond size of $150 \mathrm{~m}^{2}$ (Lathrop et al. 2000). The dominant vegetation on the marsh plain in the study area, and surrounding all study ponds, is smooth cordgrass Spartina alterniflora.

Mummichogs are typically distributed in intertidal and subtidal marsh areas on the east coast of North America (Kneib 1997). Though several fish species are resident in marsh ponds in the Sheepshead Meadows marsh (e.g. F. luciae, Gasterosteus aculeatus, Cyprinodon variegatus, Lucania parva, Menidia beryllina; Szedlmayer \& Able 1996, Able et al. 2005), the mummichog is the most abundant fish species inhabiting marsh ponds in New Jersey (Able \& Szedlmayer 1996). We sampled mummichog populations in 6 marsh ponds adjacent to the Rutgers University Marine Field Station (RUMFS; Fig. 1).

We installed Onset Tidbit data loggers in all study ponds; these recorded temperature continuously over the study period. Daily tide fluctuations were measured with a gas-purged tide gauge (Metercraft) attached to a continuous chart recorder located immediately adjacent to the study area. We monitored marsh flooding of the individual study ponds by placing tide staffs (meter sticks to which narrow plastic cups were attached at $5 \mathrm{~cm}$ intervals) at the perimeter of each pond which we used to estimate the minimum tide level required to flood each pond. To obtain an estimate of the total number of floods occurring at a pond, we summed the occasions when the main tide gauge recorded a tide level greater than the tide level required to fill the bottom cup of the tide staff at each pond (Hunter et al. 2006).

Of the 6 marsh ponds chosen for study, we kept 4 in their natural state (i.e. open) and enclosed 2 others 


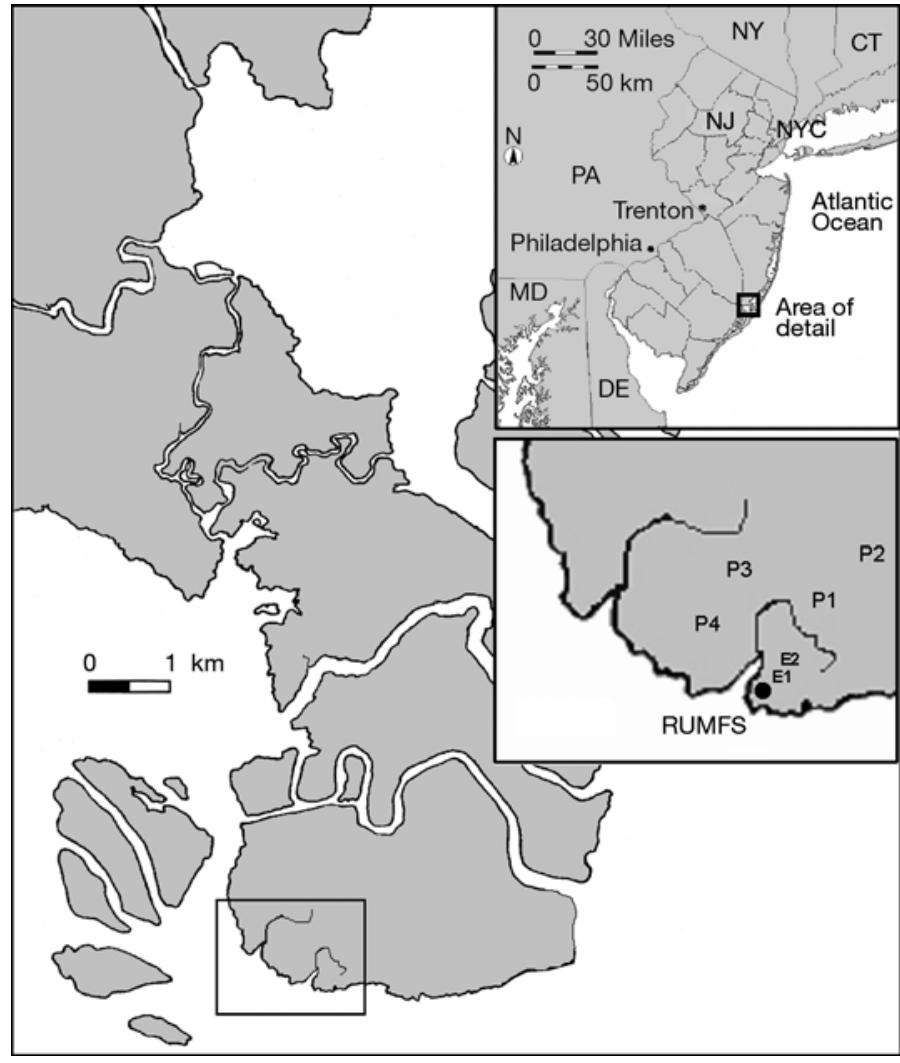

Fig. 1. Sheepshead Meadows salt marsh, New Jersey, USA. Inset shows location of open study ponds (P1-P4) and enclosures (E1, E2) in the vicinity of Rutgers University Marine Field Station (RUMFS)

(Fig. 1). Data collected from enclosed ponds were used to estimate natural mortality of mummichogs in ponds (see 'Estimation of natural mortality'). We used intermediate sized ponds of 40 to $110 \mathrm{~m}^{2}$ surface area (see Table 1) to ensure that there would be a sufficient number of fish available for marking in each pond. We chose study ponds that would be susceptible to flooding associated with spring tides in the study area (Halupa \& Howes 1995). Because marsh surface flooding can be very infrequent during the summer months at this location (Halupa \& Howes 1995), we chose to sample the study ponds once per month to provide opportunities for marsh flooding to occur between sampling periods. Aquatic vegetation was sparse in all study ponds.

Mark-recapture techniques. We collected data on mummichog populations in the 6 study ponds by capturing, marking and recapturing fish. We used the same techniques in both open and enclosed ponds, but the timing and duration of data collection in the 2 types of study ponds differed. There were 2 stages of data collection for each mark-recapture sample: (1) fish were captured, enumerated and marked, and (2) fish were captured, enumerated and checked for previous marks. We repeated the capture, mark and recapture process 3 consecutive times at each pond in each month to collect a multiple-day recapture data series. In total, we collected 4 independent monthly series of mark-recapture data at each open pond (April-July, $\mathrm{n}=16$ ). For the enclosed ponds, data were gathered over 3 mo (May-July, $\mathrm{n}=12$ ).

For the initial capture stage, we deployed 10 cylindrical wire-mesh traps (6 mm mesh) in each pond (12 $\pm 2 \mathrm{~h}$ soak time). Mummichogs caught in the traps were immediately brought to the lab, and individuals were given a mark in the dorsal or lateral musculature by a subcutaneous injection of fluorescent acrylic paint (Lotrich \& Meredith 1974, Smith \& Able 1994). Each month, we marked mummichogs with a different color and body location. The combination of mark color and location made it possible to determine the origin of the fish and whether it had been previously captured in a pond. We removed and recorded any dead or moribund fish from all samples. Mortality attributed to marking was less than $1 \%$ within all monthly assessments.

Live, marked mummichogs from a given pond were released simultaneously back to their pond of origin. We waited at least $6 \mathrm{~h}$ for the released fish to disperse within the pond before setting traps for recapture. To recapture marked fish, we redeployed the same wire-mesh traps in the ponds (April and May: $14 \pm 2 \mathrm{~h}$ soak time; June and July: $8 \pm 2$ h reduced soak time to avoid mortality in traps from hypoxia). Captured fish were brought back to the lab where we inspected each individual for marks under a black light. Marked and unmarked individuals were recorded, and 250 randomly selected individuals were measured. At that time, we gave all unmarked individuals the mark assigned to the current monthly sample. We redeployed the same traps on 2 consecutive days to complete the monthly $3 \mathrm{~d}$ markrecapture data series. We used the ratio of marked and unmarked fish to estimate pond population size (see 'Population estimates'). We used the changes in the number of marked fish between successive monthly data series to estimate rates of emigration, immigration, recruitment and mortality.

Mark retention assessment. To ensure the marking method did not contribute greatly to reduced population estimate reliability, we assessed how well mummichogs retained marks over the study period in the laboratory. In previous studies, retention of subcutaneous acrylic paint marks in mummichogs has been reported to last as long as 7 mo with a very low impact on mortality (Lotrich \& Meredith 1974, Smith \& Able 1994). 
On 5 June, we collected 150 mummichogs and marked each fish on the dorsal and lateral musculature using the same technique as the field samples. We held the marked fish in $380 \mathrm{l}$ circular tanks with circulating seawater at ambient creek temperature to examine mark retention over the course of study. Fish were fed flake food daily and examined periodically to determine mark loss. All marks were highly visible within the first $50 \mathrm{~d}$ from initial marking. We relied on a black light to detect dorsal marks after $50 \mathrm{~d}$. Ten percent of dorsal marks were lost after $80 \mathrm{~d}$. Marks injected in the lateral musculature of the fish were highly visible throughout the $80 \mathrm{~d}$ period that mark retention was assessed. This assessment showed that the marking technique employed in our field samples was subject to little or no mark loss between the monthly periods used for assessing migration rates.

Population estimates. Two of the most commonly used methods to estimate fish population size are mark-recapture and catch per unit effort (CPUE). In the present study, we made population estimates from mark-recapture rather than CPUE data, as the latter have been shown to produce inaccurate population estimates when mummichogs are collected with wire mesh traps, as their ability to escape from these openended traps can vary with time (Kneib \& Craig 2001).

We assumed that marsh ponds under non-flooding conditions would be acceptable 'closed' habitats from a population modelling perspective (Cowley \& Whitfield 2002), and conducted the monthly mark-recapture assessments at least $5 \mathrm{~d}$ prior to the predicted high tide of each month. However, on 3 occasions during the study period, one or more of the ponds flooded during the collection of recapture data, affecting 12 out of the 48 samples taken. We employed the Petersen method, which uses the ratio of recaptured animals (number captured/number marked) in a single random sample to estimate population size:

$$
N=\left(A \times C_{1}\right) / C_{2}
$$

where $N$ is the estimated population size, $A$ is the number of fish marked and released, $C_{1}$ is the number of fish in the recapture sample and $C_{2}$ is the number of fish recaptured (Seber 1973).

Three main assumptions of the Petersen model are: (1) the population is closed, i.e. there is no birth, death, immigration or emigration; (2) all fish are equally catchable; and (3) marks are not missed or lost. To meet the first assumption of the Petersen method, we calculated abundance estimates of mummichogs in ponds using only data that were collected prior to any flooding at a pond ( $\mathrm{n}=36$ population estimates) and when more than one monthly estimate could be used in a pond, we calculated a mean population estimate for that month. The same procedures to estimate popu- lation size in open ponds were used for enclosed ponds. We determined mummichog density in each study pond by dividing the population estimate by the estimated surface area.

Estimation of natural mortality. We constructed 2 artificial pond enclosures that eliminated fish movement (immigration and emigration) and used data from enclosed pond populations to estimate the natural mortality rate of mummichogs in marsh ponds. On 13 May, 2 marsh ponds were artificially enclosed using $6 \mathrm{~mm}$ nylon mesh material embedded $0.25 \mathrm{~m}$ into the marsh surface, $1 \mathrm{~m}$ outside the perimeter of each pond. The mesh was stapled to $2.5 \times 10 \mathrm{~cm}$ wooden stakes driven into the marsh surface every $2.5 \mathrm{~m}$. Horizontal stakes were nailed to the upright stakes to provide stability. The height of each enclosure was $0.75 \mathrm{~m}$.

Mortality $(M)$ between 2 consecutive monthly population assessments $(t-1, t)$ was assumed from the monthly population change in the 2 enclosed ponds (ep). We included a recruitment term $(R)$ to adjust for individuals that would grow large enough to be captured with the sampling gear between experiments. Mortality was calculated as follows:

$$
M_{t-1, t}=N_{t-1(\mathrm{ep})}-\left[N_{t(\mathrm{ep})}-R_{t-1, t(\mathrm{ep})}\right]
$$

And in percentage terms:

$$
\% M_{t-1, t}=M_{t-1, t} / N_{t-1}
$$

The mortality rate estimated between May and June was applied to the period between April and May because enclosures were not built until mid-May.

We assumed that the average mortality rate in the enclosures was equal to mortality in the open ponds and used this information to calculate immigration and emigration rates in open ponds. The number of mortalities in open ponds was determined by multiplying the mean monthly mortality rate by the total number of marked individuals from the monthly capture-recapture sample.

Estimation of emigration, recruitment and immigration. The analysis of population dynamics of mummichogs in marsh ponds was centred on estimating the monthly emigration rate of mummichogs from each study pond. We used the mark-recapture data to estimate the number of remaining marked fish in a pond from the previous month's mark-recapture series, and to determine the rate of emigration from a pond between monthly samples. In addition, we estimated the recruitment rate of mummichogs (unmarked, 40 to $45 \mathrm{~mm}$ TL) to the sampling gear between monthly sampling events at each study pond. Lastly, combining the estimates of emigration, recruitment and mortality parameters, we calculated the number of immigrants to a pond and determined the rate of immigration algebraically. 
Emigration: The emigration rate $\left(\% E_{t-1, t}\right)$ of mummichogs from a pond between 2 consecutive monthly samples is related to the change in the number of marked fish from one month to the next $\left(X_{t}, X_{t-1}\right)$, with the latter adjusted for loss due to mortality (assumed from the enclosed ponds). The current number of marked fish remaining from the previous sample population $\left(X_{t}\right)$ was adjusted for the proportion of marked fish present but not counted by multiplying the marked captures by the recapture rate of the current month $\left(R C_{t}\right)$ :

$$
X_{t \text {-adj }}=X_{t} \times R C_{t}
$$

Losses in the number of marked fish from time $t-1$ to $t$ would occur as the result of emigration and natural mortality. The number of emigrants between 2 assessment periods was thus calculated as:

$$
E_{t-1, t}=\left[\left(X_{t-1}-X_{t \text {-adj }}\right) / X_{t-1}\right]-\left[\% M / 100 \times X_{t-1}\right]
$$

and the emigration rate for the period was calculated as:

$$
\% E_{t-1, t}=100 \times E_{t-1, t} / N_{t-1}
$$

Recruitment: We estimated the number of recruits in the current population $\left(N_{t}\right)$ by assuming that all individuals 40 to $45 \mathrm{~mm}$ TL are in fact recruits (i.e. were not part of the previous population surveyed as we have defined it). Capture efficiency of wire mesh traps is not effective for mummichogs $<40 \mathrm{~mm}$ TL (Teo 1999). Therefore, $N_{t}$ includes individuals that would have been too small to be effectively captured by the sampling gear in previous samples. We assumed on the basis of spring and summer growth trajectories that mummichogs $<40 \mathrm{~mm}$ TL at our study site grow in length at an average rate of $5 \mathrm{~mm} \mathrm{mo}^{-1}$ (Hunter 2004). Based on measurements from a subsample, the proportion of fish that were present in the 40 to $45 \mathrm{~mm}$ range $\left(\mathrm{pN}_{t(40-45)}\right)$ was used to account for the part of the population that would not have been counted in previous estimates. Thus:

$$
R_{t-1, t}=\mathrm{p} N_{t(40-45)} / N_{t}
$$

We then determined recruitment rate in percentage terms as follows:

$$
\% R_{t-1, t}=100 \times R_{t-1, t} / N_{t-1}
$$

Immigration: To estimate the number of individuals that immigrated into a pond between monthly samples, we rearranged the basic population dynamics equation where all other variables were known and solved for immigration $(I)$ :

$$
I_{t-1, t}=N_{t}-\left(N_{t-1}+R_{t-1}-E_{t-1, t}-M_{t-1, t}\right)
$$

where $N_{t}$ is the population estimate for the current month.
Percent immigration was determined as follows:

$$
\% I_{t-1, t}=I_{t-1, t} / N_{t-1}
$$

Because of the indirect manner in which it was estimated, the immigration rate was highly dependent on the mortality rate assumed from the enclosed ponds. Mortality rates could have been overestimated by our procedures simply due to the use of enclosures, or due to the higher temperatures and/or fewer occurrences of flooding in the enclosed ponds (see Table 1). On the other hand, mortality rates could have been underestimated because population densities in the enclosed ponds were lower than those of the unenclosed ponds. To determine the degree to which spring and summer trends in immigration are affected by the mortality rate, we performed a sensitivity analysis on the monthly rate of immigration by increasing and decreasing the mortality rate by 25 and $50 \%$.

Relationships between environmental variables and emigration rates. We tested our predictions on the effects of flood frequency, temperature and fish density on emigration rates using the spring-summer means (monthly data averaged for each pond, $\mathrm{n}=4$ ) and individual monthly estimates made in each pond $(\mathrm{n}=12)$. Univariate relationships using the pond means were examined with Pearson correlations. To test for relationships with the monthly data, we used analysis of covariance (ANCOVA), with flood frequency, temperature or fish density as the covariate, and site as the independent variable. Significance of the covariate was then tested using the mean square error and degrees of freedom from the site $\times$ covariate interaction term.

\section{RESULTS}

Mean monthly temperature in the ponds increased gradually over the study period from 18.0 to $27.0^{\circ} \mathrm{C}$. Flooding occurred in all ponds throughout the study period (Table 1; mean number of days flooded $\pm \mathrm{SE}=$ $39.3 \pm 3.1)$.

The total number of mummichogs that were caught, marked and released in the 4 open ponds across all monthly mark-recapture samples was 17878. The body lengths of captured and recaptured mummichogs ranged from 35 to $109 \mathrm{~mm}$ TL, and length distributions were similar among ponds (Table 2). The average recapture rate for all monthly mark-recapture samples in open ponds was $72.3 \%$ (range $=44$ to $96 \%$; Table 2). Recapture rates were also high in the enclosed ponds, often exceeding $90 \%$. Changes in population estimates over the study period suggested a consistent decline in the density of mummichogs in ponds after the peak spawning period ended in May 
Table 1. Physical characteristics of open (Ponds 1 to 4) and enclosed ponds (Enclosures 1 and 2). Pond locations are shown in Fig. 1. Tide height that flooded a pond was estimated by using tide staffs at the perimeter of each pond; no tide staffs were placed at the enclosures. Enclosures were observed to be flooded on 25 June and 11 July. The high tide level recorded by a central tide gauge at the Marine Field Station was used to estimate the tide level required to flood the enclosures

\begin{tabular}{|c|c|c|c|c|c|}
\hline Site & $\begin{array}{c}\text { Population assessment } \\
\text { interval }\end{array}$ & $\begin{array}{l}\text { Surface area } \\
\left(\mathrm{m}^{2}\right)\end{array}$ & $\begin{array}{l}\text { Mean depth (m) } \\
\text { (SD) }\end{array}$ & $\begin{array}{c}\text { Mean pond } \\
\text { temperature }\left({ }^{\circ} \mathrm{C}\right)\end{array}$ & $\begin{array}{c}\text { Estimated } \\
\text { number of floods }\end{array}$ \\
\hline Pond 1 & $\begin{array}{l}\text { Apr-May } \\
\text { May-Jun } \\
\text { Jun-Jul }\end{array}$ & 44 & $0.38(0.4)$ & $\begin{array}{l}17.7 \\
23.7 \\
26.7\end{array}$ & $\begin{array}{l}11 \\
17 \\
12\end{array}$ \\
\hline Pond 2 & $\begin{array}{l}\text { Apr-May } \\
\text { May-Jun } \\
\text { Jun-Jul }\end{array}$ & 41 & $0.39(0.5)$ & $\begin{array}{l}17.8 \\
24.1 \\
26.6\end{array}$ & $\begin{array}{r}8 \\
14 \\
7\end{array}$ \\
\hline Pond 3 & $\begin{array}{l}\text { Apr-May } \\
\text { May-Jun } \\
\text { Jun-Jul }\end{array}$ & 69 & $0.48(0.7)$ & $\begin{array}{l}18.1 \\
24.3 \\
27.3\end{array}$ & $\begin{array}{l}12 \\
18 \\
16\end{array}$ \\
\hline Pond 4 & $\begin{array}{l}\text { Apr-May } \\
\text { May-Jun } \\
\text { Jun-Jul }\end{array}$ & 110 & $0.32(0.5)$ & $\begin{array}{l}18.4 \\
24.5 \\
27.3\end{array}$ & $\begin{array}{l}10 \\
18 \\
12\end{array}$ \\
\hline Enclosure 1 & $\begin{array}{l}\text { Apr-May } \\
\text { May-Jun } \\
\text { Jun-Jul }\end{array}$ & 40 & $0.35(0.4)$ & $\begin{array}{c}- \\
25.1 \\
27.7\end{array}$ & $\begin{array}{l}- \\
6 \\
4\end{array}$ \\
\hline Enclosure 2 & $\begin{array}{l}\text { Apr-May } \\
\text { May-Jun } \\
\text { Jun-Jul }\end{array}$ & 74 & $0.41(0.3)$ & $\begin{array}{c}- \\
24.6 \\
27.0\end{array}$ & $\begin{array}{r}- \\
6 \\
4\end{array}$ \\
\hline
\end{tabular}

Table 2. Fundulus heteroclitus. Body size, population size, recapture rate, cumulative number of captures and recaptures and mummichog density for all monthly assessments (April to July) in open ponds and enclosures. Only mummichogs $>40 \mathrm{~mm}$ TL were given a mark and used in population assessments. Mean abundance estimates omit recapture data for $1\left({ }^{\mathrm{a}}\right)$ or $2\left({ }^{\mathrm{b}}\right)$ recap-

ture samples that were affected by flooding at the pond, thus violating closed system assumptions of the population model

\begin{tabular}{|c|c|c|c|c|c|c|c|}
\hline Site & Month & $\begin{array}{c}\text { Size range } \\
\text { of captures } \\
(\mathrm{mm} \mathrm{TL})\end{array}$ & $\begin{array}{c}\text { Mean abundance } \\
\text { estimate } \\
\text { (SE) }\end{array}$ & $\begin{array}{l}\text { Mean } \\
\text { recapture } \\
\text { rate }\end{array}$ & $\begin{array}{l}\text { Cumulative no. } \\
\text { captures }\end{array}$ & $\begin{array}{l}\text { Cumulative no. } \\
\text { recaptures }\end{array}$ & $\begin{array}{l}\text { Density } \\
\left(\text { fish } \mathrm{m}^{-2} \text { ) }\right.\end{array}$ \\
\hline Pond 1 & $\begin{array}{l}\text { Apr } \\
\text { May } \\
\text { Jun } \\
\text { Jul }\end{array}$ & $\begin{array}{l}35-96 \\
37-95 \\
40-86 \\
35-77\end{array}$ & $\begin{array}{l}1137(182)^{\mathrm{a}} \\
936^{\mathrm{b}} \\
700(8) \\
551(19)\end{array}$ & $\begin{array}{l}0.73 \\
0.86 \\
0.96 \\
0.94\end{array}$ & $\begin{array}{r}991 \\
2036 \\
1608 \\
674\end{array}$ & $\begin{array}{r}715 \\
1609 \\
1545 \\
621\end{array}$ & $\begin{array}{l}41.43 \\
65.66 \\
25.52 \\
20.70\end{array}$ \\
\hline Pond 2 & $\begin{array}{l}\text { Apr } \\
\text { May } \\
\text { Jun } \\
\text { Jul }\end{array}$ & $\begin{array}{l}36-108 \\
37-95 \\
39-90 \\
35-86\end{array}$ & $\begin{array}{l}364(18)^{\mathrm{a}} \\
675^{\mathrm{b}} \\
589(7) \\
379(6)\end{array}$ & $\begin{array}{l}0.84 \\
0.87 \\
0.88 \\
0.94\end{array}$ & $\begin{array}{r}698 \\
1572 \\
1233 \\
359\end{array}$ & $\begin{array}{r}584 \\
1095 \\
1079 \\
310\end{array}$ & $\begin{array}{l}14.76 \\
43.38 \\
23.84 \\
16.48\end{array}$ \\
\hline Pond 3 & $\begin{array}{l}\text { Apr } \\
\text { May } \\
\text { Jun } \\
\text { Jul }\end{array}$ & $\begin{array}{l}35-109 \\
35-97 \\
41-88 \\
35-89\end{array}$ & $\begin{array}{l}1543(7)^{\mathrm{a}} \\
2582^{\mathrm{b}} \\
1949(17) \\
755(177)\end{array}$ & $\begin{array}{l}0.71 \\
0.6 \\
0.79 \\
0.44\end{array}$ & $\begin{array}{r}2034 \\
1833 \\
2333 \\
793\end{array}$ & $\begin{array}{r}1229 \\
1254 \\
1790 \\
233\end{array}$ & $\begin{array}{l}41.17 \\
47.73 \\
36.16 \\
20.76\end{array}$ \\
\hline Pond 4 & $\begin{array}{l}\text { Apr } \\
\text { May } \\
\text { Jun } \\
\text { Jul }\end{array}$ & $\begin{array}{l}35-107 \\
36-96 \\
36-95 \\
35-92\end{array}$ & $\begin{array}{l}4546(193)^{\mathrm{a}} \\
3485^{\mathrm{b}} \\
2015(395) \\
691(71)\end{array}$ & $\begin{array}{l}0.56 \\
0.44 \\
0.81 \\
0.50\end{array}$ & $\begin{array}{r}2458 \\
3025 \\
2381 \\
799\end{array}$ & $\begin{array}{r}1324 \\
1628 \\
1794 \\
401\end{array}$ & $\begin{array}{r}41.89 \\
33.14 \\
18.57 \\
7.93\end{array}$ \\
\hline Enclosure 1 & $\begin{array}{l}\text { May } \\
\text { Jun } \\
\text { Jul }\end{array}$ & $\begin{array}{l}35-80 \\
42-83 \\
35-75\end{array}$ & $\begin{array}{r}115(2) \\
83(3) \\
39(1)\end{array}$ & $\begin{array}{l}0.89 \\
0.96 \\
0.94\end{array}$ & $\begin{array}{r}192 \\
62 \\
53\end{array}$ & $\begin{array}{r}163 \\
58 \\
48\end{array}$ & $\begin{array}{l}2.7 \\
2.1 \\
0.9\end{array}$ \\
\hline Enclosure 2 & $\begin{array}{l}\text { May } \\
\text { Jun } \\
\text { Jul }\end{array}$ & $\begin{array}{l}36-103 \\
37-89 \\
35-88\end{array}$ & $\begin{array}{l}411(1) \\
362(6) \\
289(11)\end{array}$ & $\begin{array}{l}0.98 \\
0.96 \\
0.63\end{array}$ & $\begin{array}{r}1079 \\
777 \\
257\end{array}$ & $\begin{array}{r}1060 \\
749 \\
170\end{array}$ & $\begin{array}{l}5.6 \\
4.9 \\
3.8\end{array}$ \\
\hline
\end{tabular}




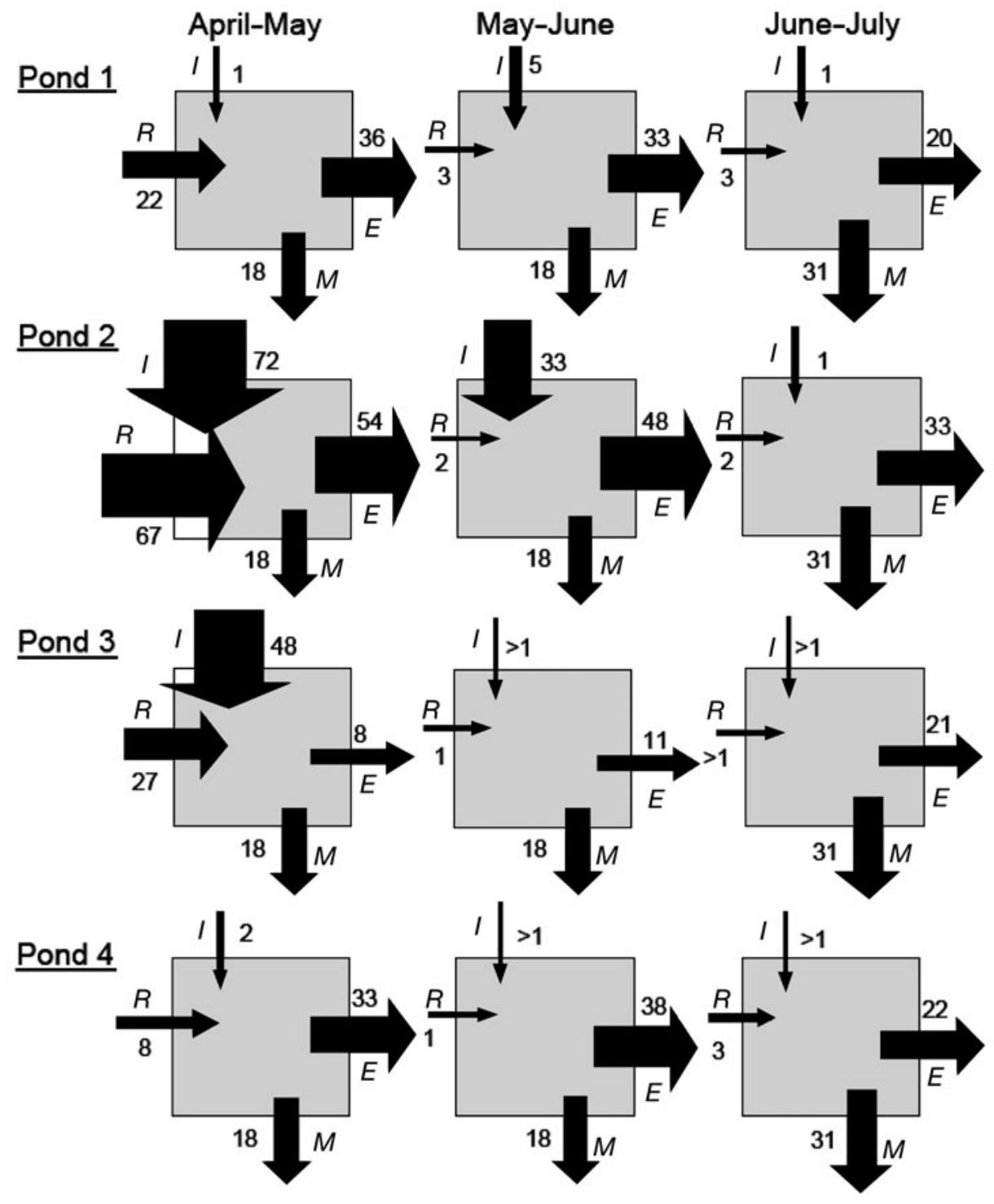

Fig. 2. Fundulus heteroclitus. Estimated rates (\%) of emigration $(E)$, immigration $(I)$ and recruitment $(R)$ in open ponds from April to July. Mortality $(M)$ in open ponds was assumed to be the same as the mean rate of mortality determined in the 2 enclosures (see 'Estimation of natural mortality')

(Table 2). Variability among replicate estimates of abundance within most monthly data series was low (Table 2).

The mean monthly emigration rate varied from 14 to $45 \%$ of the population in individual ponds, and these rates differed significantly among ponds $\left(F_{3,11}=6.73\right.$, $\mathrm{p}=0.014)$. Emigration patterns were asynchronous across ponds, with the rate of emigration declining over the period of study in 2 of the ponds, increasing over time in 1 pond and peaking mid-season in the 4 th pond (Fig. 2). The mean emigration rate of mummichogs between monthly sampling periods remained relatively constant between April and June and declined in the last assessment (pooled mean emigration rate $(\%) \pm \mathrm{SE}$ : April-May $=32.9 \pm 9.3$; May-June $=32.8 \pm 7.7$; June-July $=24.3 \pm 3.0$; Fig. 2). Data on monthly emigration rates indicate that site fidelity was generally low, as estimated mummichog emigration over the 3 mo study period varied from 28 to $71 \%$ in individual ponds. The estimated number of individuals present in April and still present in early July was also low, varying from 3 to $25 \%$.

Immigration rates declined over the study interval in all but one pond. For the May-June period, immigration rates in 3 of the 4 ponds was near, or less than, $5 \%$, indicating that immigration into ponds by mummi- 
Table 3. Fundulus heteroclitus. Sensitivity of immigration rate estimates (\%) to increases and decreases in the mortality rate assumed in the open ponds

\begin{tabular}{|llrrrrr|}
\hline \multirow{2}{*}{ Site } & $\begin{array}{l}\text { Population } \\
\text { assessment } \\
\text { interval }\end{array}$ & $\begin{array}{c}\text { Immigration } \\
\text { rate } \\
(\%)\end{array}$ & $\begin{array}{r}\text { Mortality } \\
(\%)\end{array}$ & $\begin{array}{r}+50 \\
(\%)\end{array}$ & $\begin{array}{r}-25 \\
(\%)\end{array}$ & $\begin{array}{r}-50 \\
(\%)\end{array}$ \\
\hline Pond 1 & Apr-May & $<1$ & $<1$ & $<1$ & 2 & 6 \\
& May-Jun & 5 & $<1$ & $<1$ & 10 & 14 \\
& Jun-Jul & $<1$ & $<1$ & $<1$ & 3 & 11 \\
Pond 2 & Apr-May & 72 & 67 & 62 & 76 & 80 \\
& May-Jun & 33 & 29 & 24 & 38 & 42 \\
& Jun-Jul & $<1$ & $<1$ & $<1$ & 3 & 11 \\
Pond 3 & Apr-May & 48 & 44 & 39 & 53 & 57 \\
& May-Jun & $<1$ & $<1$ & $<1$ & $<1$ & $<1$ \\
& Jun-Jul & $<1$ & $<1$ & $<1$ & $<1$ & $<1$ \\
Pond 4 4 & Apr-May & 1 & $<1$ & $<1$ & 6 & 10 \\
& May-Jun & $<1$ & $<1$ & $<1$ & $<1$ & 4 \\
& Jun-Jul & $<1$ & $<1$ & $<1$ & $<1$ & $<1$ \\
& & & & & & \\
\hline
\end{tabular}

Table 4. Pearson correlations between mean emigration rate in a pond and its mean flood frequency, temperature and mummichog density ( $\mathrm{n}=4$ ponds). See 'Materials and methods' for an explanation of emigration and immigration rate calculations

\begin{tabular}{|lcl|}
\hline Dependent variable & $\mathrm{r}$ & $\mathrm{p}$ \\
\hline Mean flood frequency & -0.96 & 0.036 \\
Mean water temperature & -0.47 & 0.53 \\
Mean Fundulus density & -0.37 & 0.63 \\
\hline
\end{tabular}

chogs is uncommon in the late spring (Fig. 2). Pond 1 showed a slightly increased rate of immigration in the May-June assessment, but this had little impact on the overall population dynamics in the pond (Fig. 2). Individual ponds showed no significant difference in monthly immigration rates $\left(F_{3,11}=2.12, \mathrm{p}=0.17\right)$. Results of the sensitivity analysis showed that assuming a $25 \%$ change in the rate of mortality estimated from the enclosed ponds generally changed the magnitude of the immigration rate by $<5 \%$ (Table 3 ).

Estimates of mortality, as determined by changes in population size of the enclosed ponds, suggested that the mortality rate of mummichogs inhabiting ponds increased between spring and summer. The estimated mean $( \pm \mathrm{SE})$ mortality rate from the 2 enclosures was $17.8 \pm 6.1 \%$ between May and June, and rose to $30.6 \pm$ $7.9 \%$ between June and July.

During the early spring, there was high recruitment of young mummichogs 40 to $45 \mathrm{~mm} \mathrm{TL}$, but recruitment was negligible in all ponds after the April-May period (average recruitment rate $(\%) \pm$ SE: April-May $=31.2 \pm 12.7 ;$ May-June $=1.2 \pm 0.5 ;$ June-July $=2.3 \pm$
0.7; Fig. 2). Recruitment between April and May in Pond 2 was estimated as $67 \%$, which accounted for a large portion of the increase in population size in that pond in May (Table 2).

The mean monthly emigration rate in a pond showed a strong negative correlation with the mean monthly frequency of pond flooding, whereas the relationships between emigration rate and both mummichog density and water temperature were weak and not significant (Table 4, Fig. 3A). The negative association between emigration rate and flood frequency was apparent in all months, and individual ponds showed a similar sequence of emigration rate and flood frequency in each month (Fig. 3B). Individual monthly pond estimates of emigration rate did not always decline with flood frequency, yet emigration rate showed a significant negative relationship with flood frequency using the monthly pond estimates when site was controlled for in the analysis $\left(F_{1,3}=47.1, \mathrm{p}=0.0063\right)$. In contrast, neither mummichog density nor water temperature was significantly correlated with the monthly emigration rate when site was controlled for $\left(F_{1,3}<1.2, \mathrm{p}>\right.$ 0.35 in both cases).

\section{DISCUSSION}

Demographic responses that contributed to mummichog population change in marsh ponds in the present study underscore the effect of habitat conditions on population dynamics over space and time (Taylor \& Taylor 1977, Hanski \& Gilpin 1991). We found a significant negative correlation between flood frequency in a pond and the rate of emigration of resident mummichogs, which suggests that high flood frequency during the summer may trigger stationary behaviour in mummichogs occupying marsh ponds. Pond temperature and fish density did not have significant effects on emigration rate. Advantages may be conferred on adult mummichogs that use pond habitats because predation risk in ponds is lower than creek habitats (Halpin 2000), and water quality and food resources are improved during flooding conditions (Weisberg et al. 1981, Kneib \& Wagner 1994, Balcombe et al. 2005, 2007).

Although there may be advantages provided by flooding, emigration by adult mummichogs from marsh ponds was continuous across the study period, suggesting a seasonal migration from marsh ponds to other marsh habitats during the spring and summer. Despite the reduction in pond population size attributed largely to emigration over the spring and summer, we hypothesize that ponds provide especially important habitat for young mummichogs during the same period. 

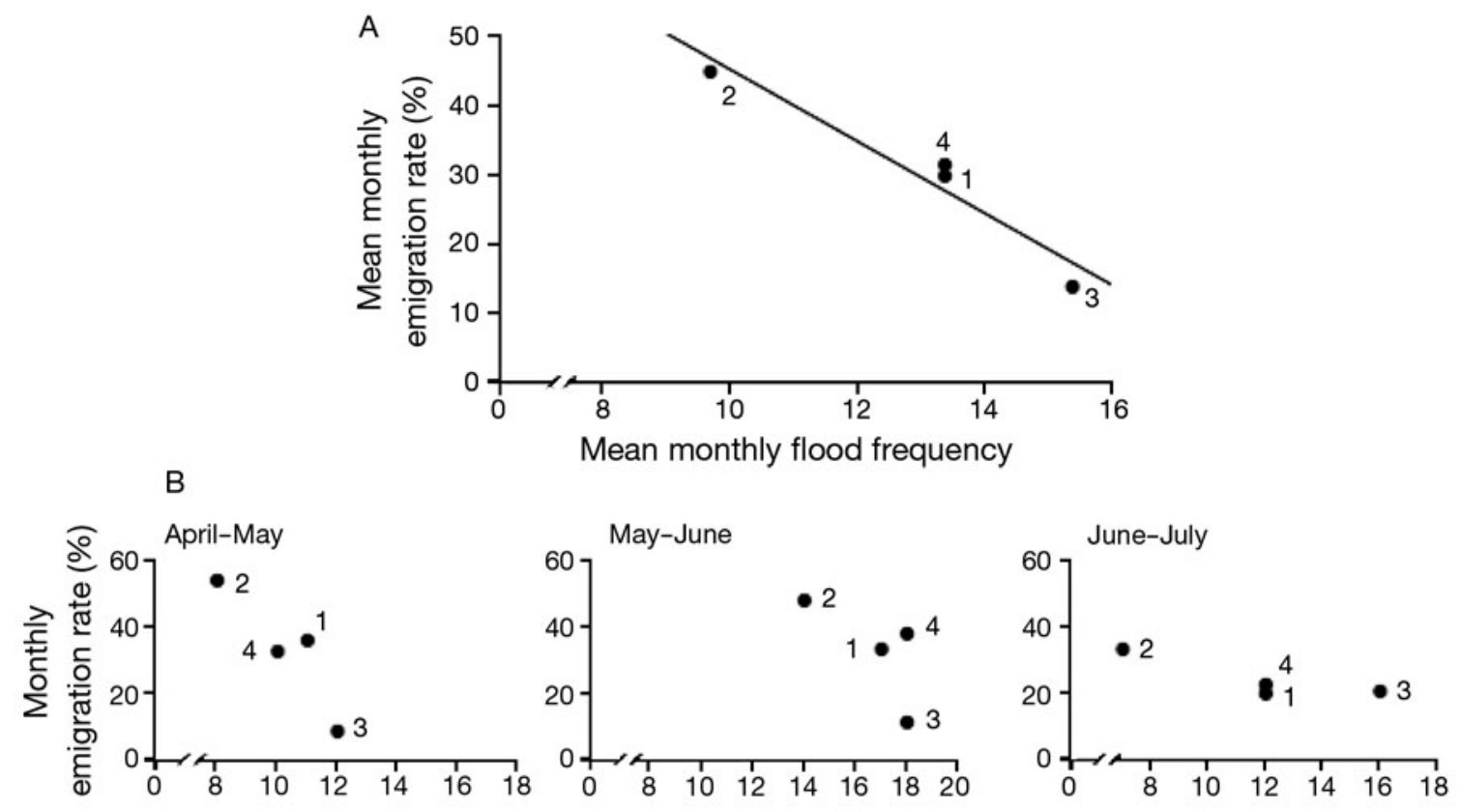

Mean monthly flood frequency

Fig. 3. Fundulus heteroclitus. Relationships between the monthly emigration rate of mummichogs and monthly flood-frequency, shown (A) as pond means averaged over all assessment periods, and (B) for each monthly assessment period. Numbers (1-4) on graphs refer to individual ponds. Best fit line in (A) is statistically significant; $r$ and $p$ values are provided in Table 4

\section{Population dynamics of mummichogs in marsh ponds}

While migration patterns among ponds in the present study were not always synchronous, emigration was the most influential factor producing changes to mummichog abundance in marsh ponds over the study period (mean of $30 \%$ ), as well as in most months in individual ponds. Mummichog emigration was high relative to mortality, recruitment and immigration rates in most monthly assessments, and rates of emigration were moderate to high (8 to $54 \%$ ) in any given month. Results from a previous study using desert pupfish Cyprinodon macularius also showed that a greater proportion of population losses from experimental ponds were attributed to emigration rather than mortality (McMahon \& Tash 1988). Given these similar patterns, emigration may be a common source of fish population decline in semi-closed habitats, at least where other suitable habitat is accessible.

Immigration was not a strong driver of population change in 2 of the 4 study ponds in the spring and was negligible in all ponds after the month of May. A sensitivity analysis on immigration estimates showed that either modest $(25 \%)$ or large $(50 \%)$ changes to the natural mortality rate would not have produced greatly altered immigration rates. We documented the highest rates of immigration during the peak period of reproductive activity of mummichogs and there was evidence of high recruitment of larval mummichogs to marsh ponds (see below). We speculate that immigration into marsh ponds in the spring may have been driven by adults from other overwintering sites such as other ponds (Smith \& Able 1994) or creeks and basins (Able \& Fahay 1998). Some of these may have been entering to spawn, as it is known that marsh ponds provide suitable habitat for larval fish (Able et al. 2005, 2006).

The decline in emigration rates from spring to summer and the corresponding increase in mortality rates suggest that there was a shift in the relative importance of migration in regulating mummichog population size in marsh ponds over the study period. Natural mortality of mummichogs increased by $60 \%$ from May to July in the enclosed ponds, such that the mortality rate accounted for $31 \%$ of the mummichog population in these ponds in July. The increase in mortality may be a result of decreased flooding during June and July, coupled with water temperature that surpassed $38^{\circ} \mathrm{C}$ in the enclosed ponds on several days during the same months. The mortality estimate made in enclosed ponds is comparable to a previous annual mortality estimate of $54 \%$ made for mummichogs Age 1 and 
older that were confined in pens in marsh creek habitats (Meredith \& Lotrich 1979).

Using recruitment dynamics and pond residency patterns from the present study, we hypothesize that individuals of this species may spend their first summer of life in their natal environment before moving to other habitats. Abundance of mummichogs 40 to 45 $\mathrm{mm}$ TL was only substantial in the spring, and we assumed that these fish were not immigrants. One study on overwintering marsh pond mummichog populations suggests that recruits in the study ponds were likely representatives of the previous year's summer cohort (Smith \& Able 1994). In addition, the peak abundance of larval mummichogs in marsh ponds occurs in June and July (Able et al. 2006), leaving a relatively short growth period for hatchlings. Further, over the 3 mo study period, monthly emigration rates indicated that site fidelity was generally low. Based on mark-recapture data, the estimated number of individuals marked in April and still present in July was also low, ranging from 3 to $25 \%$. Based on back-calculated growth estimates of mummichogs in the Sheepshead Meadows marsh (Hunter et al. 2007), most of the individuals that were resident in study ponds throughout the study period (mean length $=60.7 \mathrm{~mm}$ TL in July) would have been small fish when they were first marked in April (i.e. 40 to $45 \mathrm{~mm}$ TL). Thus, resident mummichogs may represent young-of-the-year from the previous summer. Many juvenile fishes are known to hold off movement until they are of a specific size or age (Kendall et al. 1984, Groot \& Margolis 1991), including mummichogs (Able et al. 2006). However, it is possible that some of the emigration from marsh ponds is related to a change in habitat preference by young mummichogs, as well as a seasonal habitat shift by adult fish into creek habitats where they are also abundant during summer (Tupper \& Able 2000). A future migration study using individually marked fish would be a useful way to examine some of the lifestage related migration patterns that could not be specifically determined in the present study.

In the present study, the overall immigration and emigration rates suggest a pond to creek migration course by mummichogs from spring to summer. Pond quality in mid-summer in most ponds may be sufficiently diminished to discourage pond use by mummichogs, or rather mid-summer use of other habitats may confer an unknown fitness advantage on adult mummichogs. Smith \& Able (1994) suggested a reverse migration pattern of increased pond habitation by mummichogs in the fall. Given these combined seasonal migrations, we suggest that a diversity of marsh habitats, including marsh ponds, is likely important for mummichogs, as well as seasonal marsh trophic dynamics.

\section{Habitat and demographic effects on emigration rate}

Population losses through emigration suggest that animals may be responding to habitat cues that indicate deteriorating habitat quality (Winker et al. 1995, Belanger \& Rodriguez 2002, McMahon \& Matter 2006). For example, increased rates of local movement of spiders within low quality habitats were correlated with increased emigration rates (Bonte et al. 2004), and avoidance of habitat types of diminished quality is also documented for many stream fishes (Rice 2005, Cucherousset et al. 2007). In the present study, the significant negative relationship between the mean flood frequency in a pond and its mean emigration rate is consistent with our predictions, probably because of reduced seasonal habitat-associated stress including access to food resources, high temperature and low dissolved oxygen (Balcombe et al. 2005, 2007). Flooding of marsh ponds occurred on $40 \%$ of days in the study period and was presumably sufficient to permit fish migration to and from marsh ponds between monthly mark-recapture intervals and across the spring and summer. In marsh environments, the availability of flooded marsh surface habitat is associated with variability in flood magnitude (Morris et al. 1990, Halupa \& Howes 1995). Flooding also affects access to other habitats and resources for fish (Junk et al. 1989), and may be a strong driver for many fish species for foraging (Kneib \& Wagner 1994, Balcombe et al. 2005), growth (Sommer et al. 2001, Balcombe et al. 2007) and movement (Whoriskey \& Fitzgerald 1989, Szedlmayer \& Able 1993).

Temperature is an important factor that affects the quality of fish habitat. In the present study, temperature in the study ponds increased in June and July, but was relatively cool in April and May. Temperature conditions experienced by mummichogs may also have been mediated by pond flooding during the warmest months (Schulte 2007). Ponds may not have reached the extreme temperature that would initiate a response by mummichogs, as they may only be affected (i.e. loss of equilibrium) by temperatures between 32 and $44^{\circ} \mathrm{C}$, depending on the ambient temperature to which they are acclimated (Beitinger et al. 2000, Schulte 2007). The average study pond temperature in June-July was $27^{\circ} \mathrm{C}$, whereas the maximum tolerance of mummichogs is reported to be $42^{\circ} \mathrm{C}$ (Bulger \& Tremaine 1985). Although we did not detect an association between emigration and pond temperature, moderated habitat conditions may have discouraged movement away from ponds where, relative to marsh creeks, refuge from predators is enhanced for mummichogs (Halpin 2000, Paterson \& Whitfield 2000).

Fish populations may be regulated via densitydependent habitat factors that are depleted by fish (i.e. 
resources, dissolved oxygen) (Tilman 1982, Hayes et al. 1996). Despite the high seasonal and among-pond variation in mummichog density, there was no evidence in the present study that emigration rate was influenced by density. The average $( \pm \mathrm{SE})$ fish density in open marsh ponds was $47.5 \pm 6.8 \mathrm{fish} \mathrm{m}^{-2}$ at its peak in May, but declined in to $16.5 \pm 3.0$ fish $^{-2}$ in July. The mean density in July was similar to the density estimate of 10 fish $\mathrm{m}^{-2}$ for mummichogs in a semi-isolated restored marsh habitat reported for July-October (Raposa \& Roman 2001).

In conclusion, the present study shows that emigration plays an important role in short-term and spring-summer population dynamics of mummichogs in marsh ponds, and that population dynamics are impacted by the frequency of flooding in marsh ponds. As the summer progresses, more frequent flooding may sufficiently alter the proximate factors that influence mummichog emigration. In general, tidal flooding may encourage use of pond habitats for longer periods through the spring and summer, which allows prolonged use of a habitat type that may confer fitness advantages on pond residents, given that ponds provide mummichog habitat for spawning, foraging and refuge from aquatic predators. The ecological significance of tide-mediated patterns is that tidal regime plays an important role in the transfer of energy, via fish movement, between marshes and coastal marine ecosystems. Future studies of fishes and marsh restoration projects in coastal regions should account for the influence of the tidal regime on movement, distribution and fish assemblages in marsh habitats.

Acknowledgements. Financial support for this study was provided by an Ontario Graduate Scholarship and a Rutgers University Marine Field Station Graduate Scholarship to K.L.H., and a Natural Science and Engineering Research Council (Canada) Discovery Grant to M.G.F. The study was conducted under Trent University Animal Care Permit no. 01010. Field assistance by J. Lento was greatly appreciated. We thank the staff and volunteers at the Rutgers University Marine Field Station for their assistance throughout the periods of our field work. Comments from anonymous reviewers greatly improved this manuscript. This is Rutgers University Institute of Marine and Coastal Sciences contribution no. 2009-7. This manuscript is dedicated to the late S. M. Hagan.

\section{LITERATURE CITED}

Able KW, Fahay MP (1998) The first year in the life of estuarine fishes in the Middle Atlantic Bight. Rutgers University Press, Piscataway, NJ

Able KW, Smith KJ, Hagan SM (2005) Fish composition and abundance in New Jersey salt marsh pools: sampling technique effects. Northeast Nat 12:485-502

Able KW, Hagan SM, Brown SA (2006) Habitat use, movement, and growth of young-of-the-year Fundulus spp. in southern New Jersey salt marshes: comparisons based on tag/recapture. J Exp Mar Biol Ecol 335:177-187

Balcombe SR, Bunn SE, McKenzie-Smith FJ, Davies PM (2005) Variability of fish diets between dry and flood periods in an arid zone floodplain river. J Fish Biol 67: 1552-1567

Balcombe SR, Bunn SE, Arthington AH, Fawcett JH, McKenzie-Smith FJ, Wright A (2007) Fish larvae, growth and biomass relationships in an Australian arid zone river: links between floodplains and waterholes. Freshw Biol 52: 2385-2398

> Beitinger TL, Bennett WA, McCauley RW (2000) Temperature tolerances of North American freshwater fishes exposed to dynamic changes in temperature. Environ Biol Fishes 58: $237-275$

Belanger G, Rodriguez MA (2002) Local movements as a measure of habitat quality in stream salmonids. Environ Biol Fishes 64:155-164

Bonte D, Lens L, Maelfait JP (2004) Lack of homeward orientation and increased mobility result in higher emigration rates from low-quality fragments in a dune wolf spider. J Anim Ecol 73:643-650

Bulger AJ, Tremaine SC (1985) Magnitude of seasonal effects on heat tolerance in Fundulus heteroclitus. Physiol Zool 58:197-204

> Childers DL, Day JW Jr, Muller RA (1990) Relating climatological forcing to coastal water levels in Louisiana estuaries and the potential importance of El Niño-Southern Oscillation events. Clim Res 1:31-42

> Cowley PD, Whitfield AK (2002) Biomass and production estimates of a fish community in a small South African estuary. J Fish Biol 61(Suppl A):74-89

Cucherousset J, Paillisson JM, Carpentier A, Chapman LJ (2007) Fish emigration from temporary wetlands during drought: the role of physiological tolerance. Fundam Appl Limnol 168:169-178

> Fretwell SD, Lucas HL Jr (1969) On territorial behaviour and other factors influencing habitat distribution in birds. I. Theoretical development. Acta Biotheor 19:16-36

- Fritz ES, Meredith WH, Lotrich VA (1975) Fall and winter movements and activity level of the mummichog, Fundulus heteroclitus, in a tidal creek. Chesap Sci 16:211-215

Froneman PW (2002) Response of the plankton to three different hydrological phases of the temporarily open/closed Kasouga estuary, South Africa. Estuar Coast Shelf Sci 55: $535-546$

Groot C, Margolis L 1991. Pacific salmon life histories. UBC Press, Vancouver

> Halpin PM (1997) Habitat use patterns of the mummichog, Fundulus heteroclitus, in New England. I. Intramarsh variation. Estuaries Coasts 20:618-625

Halpin PM (2000) Habitat use by an intertidal salt-marsh fish: trade-offs between predation and growth. Mar Ecol Prog Ser 198:203-214

> Halupa PJ, Howes BL (1995) Effects of tidally mediated litter moisture content on decomposition of Spartina alterniflora and S. patens. Mar Biol 123:379-391

> Hanski I, Gilpin M (1991) Metapopulation dynamics: brief history and conceptual domain. Biol J Linn Soc 42:3-16

> Hayes DB, Ferreri CP, Taylor WW (1996) Linking fish habitat to their population dynamics. Can J Fish Aquat Sci 53: 383-390

Hunter KL (2004) Habitat influences on the reproductive allocation, growth and population dynamics of the mummichog (Fundulus heteroclitus) in a coastal salt marsh. MSc thesis, Trent University, Peterborough, ON

Hunter KL, Fox DA, Brown LM, Able KW (2006) Responses of resident marsh fishes to stages of Phragmites australis 
invasion in three mid-Atlantic estuaries. Estuaries Coasts 29:487-498

Hunter KL, Fox MG, Able KW (2007) Habitat influences on reproductive allocation and growth of the mummichog (Fundulus heteroclitus) in a coastal salt marsh. Mar Biol 151:617-627

Junk WJ, Bayley PB, Sparks RE (1989) The flood pulse concept in river-floodplain systems. Can Spec Publ Fish Aquat Sci 106:110-127

Kendall AW Jr, Ahlstrom EH, Moser HG (1984) Early life stages of fishes and their characters. In: Moser HG, Richards WJ, Cohen DM, Fahay MP, Kendall AW Jr, Richardson SL (eds) Ontogeny and systematics of fishes. Special Publication 1. American Society of Ichthyologists and Herpetologists, Lawrence, KS, p 11-22

Kneib RT (1986) The role of Fundulus heteroclitus in salt marsh trophic dynamics. Am Zool 26:259-269

Kneib RT (1997) Early life stages of resident nekton in intertidal marshes. Estuaries 20:214-230

Kneib RT, Craig AH (2001) Efficacy of minnow traps for sampling mummichogs in tidal marshes. Estuaries 24:884-893

Kneib RT, Stiven AE (1978) Growth, reproduction, and feeding of Fundulus heteroclitus (L.) on a North Carolina salt marsh. J Exp Mar Biol Ecol 31:121-140

Kneib RT, Wagner SL (1994) Nekton use of vegetated marsh habitats at different stages of tidal inundation. Mar Ecol Prog Ser 106:227-238

Kristan WB III (2003) The role of habitat selection behavior in population dynamics: source-sink systems and ecological traps. Oikos 103:457-468

Lathrop RG, Cole MB, Showalter RD (2000) Quantifying the habitat structure and spatial pattern of New Jersey (USA) salt marshes under different management regimes. Wetlands Ecol Manag 8:163-172

Lotrich VA (1975) Summer home range and movement of Fundulus heteroclitus (Linnaeus) in a tidal creek. Ecology 56:191-198

Lotrich VA, Meredith WH (1974) A technique and the effectiveness of various acrylic colors for subcutaneous marking of fish. Trans Am Fish Soc 103:140-142

Lucas MC, Baras E (2001) Migration of freshwater fishes. Iowa State University Press, Ames, IA

McMahon TE, Matter WJ (2006) Linking habitat selection, emigration and population dynamics of freshwater fishes: a synthesis of ideas and approaches. Ecol Freshw Fish 15: $200-210$

McMahon TE, Tash JC (1988) Experimental analysis of the role of emigration in population regulation of desert pupfish. Ecology 69:1871-1883

Meredith WH, Lotrich VA (1979) Production dynamics of a tidal creek population of Fundulus heteroclitus (Linnaeus). Estuar Coast Mar Sci 8:99-118

Morris JT, Kjerfve B, Dean JM (1990) Dependence of estuarine productivity on anaomalies in mean sea level. Limnol Oceanogr 35:926-930

Paterson AW, Whitfield AK (2000) Do shallow-water habitats function as refugia for juvenile fishes? Estuar Coast Shelf

Editorial responsibility: Romuald Lipcius, Gloucester Point, Virginia, USA
Sci 51:359-364

Raposa KB, Roman CT (2001) Seasonal habitat-use patterns of nekton in a tide-restricted and unrestricted New England salt marsh. Wetlands 21:451-461

Rice JC (2005) Understanding fish habitat ecology to achieve conservation. J Fish Biol 67 (Suppl B):1-22

Schulte PM (2007) Responses to environmental stressors in an estuarine fish: interacting stressors and the impacts of local adaptation. J Therm Biol 32:152-161

Seber GAF (1973) The estimation of animal abundance and related parameters. Hafner Press, New York

Smith KJ, Able KW (1994) Salt-marsh tide pools as winter refuges for the mummichog, Fundulus heteroclitus, in New Jersey. Estuaries Coasts 17:226-234

Smith KJ, Able KW (2003) Dissolved oxygen dynamics in salt marsh pools and its potential impacts on fish assemblages. Mar Ecol Prog Ser 258:223-232

Sommer TR, Nobriga M, Harrell W, Batham W, Kimmerer W (2001) Floodplain rearing of juvenile Chinook salmon: evidence of enhanced growth and survival. Can J Fish Aquat Sci 58:325-333

> Szedlmayer ST, Able KW (1993) Ultrasonic telemetry of age-0 summer flounder, Paralichthys dentatus, movements in a southern New Jersey estuary. Copeia 1993:728-736

Szedlmayer ST, Able KW (1996) Patterns of seasonal availability and habitat use by fishes and decapod crustaceans in a southern New Jersey estuary. Estuaries Coasts 19:697-709

Taylor LR, Taylor RAJ (1977) Aggregation, migration and population mechanics. Nature 265:415-421

Teo SLH (1999) Population dynamics of the mummichog, Fundulus heteroclitus, in a restored salt marsh. MS thesis, Rutgers University, New Brunswick, NJ

Tilman D (1982) Resource competition and community structure. Princeton University Press, Princeton, NJ

Tupper M, Able KW (2000) Movements and food habits of striped bass (Morone saxatilis) in Delaware Bay (USA) salt marshes: comparison of a restored and a reference marsh. Mar Biol 137:1049-1058

Valiela I, Rutecki D, Fox S (2004) Salt marshes: biological controls of food webs in a diminishing environment. J Exp Mar Biol Ecol 300:131-159

Weisberg SB, Lotrich VA (1982) The importance of an infrequently flooded intertidal marsh surface as an energy source for the mummichog Fundulus heteroclitus: an experimental approach. Mar Biol 66:307-310

- Weisberg SB, Whalen R, Lotrich VA (1981) Tidal and diurnal influence on food consumption of a salt marsh killisfish Fundulus heteroclitus. Mar Biol 61:243-246

Werner EE, Gilliam JF, Hall DJ (1983) An experimental test of the effects of predation risk on habitat use in fish. Ecology 64:1540-1548

- Whoriskey FG, Fitzgerald GJ (1989) Breeding-season habitat use by sticklebacks (Pisces: Gasterosteidae) at Isle Verte, Quebec. Can J Zool 67:2126-2130

> Winker K, Rappole JH, Ramos MA (1995) The use of movement data as an assay of habitat quality. Oecologia 101: $211-216$

Submitted: October 17, 2009; Accepted: July 9, 2009

Proofs received from author(s): September 14, 2009 